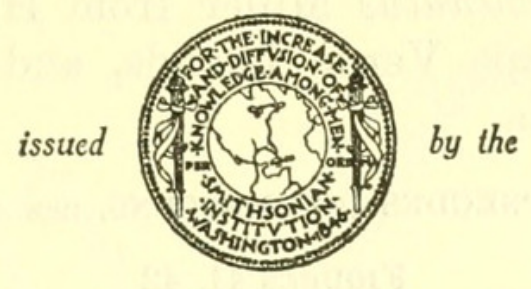

SMITHSONIAN INSTITUTION

U. S. NATIONAL MUSEUM

\title{
A NEW SPECIES OF APSEUDID CRUSTACEAN OF THE GENUS SYNAPSEUDES FROM NORTHERN CALIFORNIA (TANAIDACEA)
}

\section{By Robert J. Menzies}

AN apparently new species of apseudid crustacean is here described from specimens collected at various localities in northern California. For the loan of the Monterey County specimens I am indebted to Dr. Frank A. Pitelka, of the University of California; and for the gift of the San Mateo County specimens Miss Margaret Barr, graduate student at the Pacific Marine Station, Marin County, Calif., deserves special thanks.

This is, to my knowledge, the second record of an intertidal marine apseudid from the California coast, the first being that of Dalapseudes pedispinis Boone, which was collected from Laguna Beach, Calif. Specimens of Synapseudes can be easily distinguished from those of Dalapseudes by their lack of pleopods. Three pairs of pleopods occur in Datapseudes (Boone, 1923, p. 147).

\section{Family APSEUDIDAE}

\section{Genus SYNAPSEUDES Miller, 1940}

Genotype: Synapseudes minutus Miller, 1940, by original designation.

Miller established Synapseudes for eye-bearing apseudid Chelifera having a three-segmented pleon and a complete absence of pleopods. His statement (Miller, 1940, p. 313) that "this is also the first case of complete absence of pleopoda in this family" is contradicted by Whitelegge's (1901, p. 213) report of a complete absence of pleopods in some specimens of Pagurapseudes spinipes Whitelegge and also by Vanhöffen's (1914, p. 464) similar statement concerning Pagurapseudes 
heterocheles Vanhöffen. Three species appear to belong in Synapseudes. They are S. minutus Miller from Hawaii, S. heterocheles (Vanhöffen) from Cape Verde Islands, and $S$. intumescens, new species, from California.

\section{SYNAPSEUDES INTUMESCENS, new species}

\section{Figures 41, 42}

Holotype.-Female with partially developed oostegites; length 2.0 $\mathrm{mm}$., width at widest part of third peraeon somite $0.4 \mathrm{~mm}$.

Allotype.-Length $1.6 \mathrm{~mm}$., width $0.4 \mathrm{~mm}$.

Figured paratype.-Female; length $1.6 \mathrm{~mm}$., width $0.6 \mathrm{~mm}$.

Diagnosis.-Eyes lateral, bulging slightly. Rostrum bifurcated. Lateral borders of pleon somites 2 and 3 extending somewhat posteriorly and having truncate apex beset with tuberculations and a seta. Pleotelson with acutely pointed apex, above which is a narrow, coneshaped, setiferous papilla, lateral and anterior to which are two widely conical setiferous papillae. Inner branch of uropods composed of four segments, outer branch two-jointed. Inner margin of first antenna with conspicuous spines. Second antenna having five segments. Last joint of mandibular palp bearing two ciliated setae.

Character of body.-Entire animal appears elongated and is more attenuated posteriorly than anteriorly. Integument thick, heavily calcified, chalky white in color. Tips of gnathopods black.

Carapace.-Carapace longer than wide; eyes bulging and with a lateral convexity immediately posterior to them. Rostrum bifurcated and margined with sharp tubercles. Two elevated circular swellings are located one on each side of midline posterior to eyes and are followed by a wider pair of perhaps less elevated swellings. Posterior border of carapace widely convex. A single long seta located on each side of carapace posterior to eyes.

Peraeon.-First somite fused with head to form carapace. Second and third somites similar and with a seta and three lateral elevations on each side of midline; margin of first lateral elevation extending the length of second somite and possessing tuberculations at anterior angle; second lateral elevation of second somite similar to first lateral elevation and with tubercles and a seta at anterior angle and tubercles on posterior angle; third lateral elevation (marginal) of second somite longer and larger than second lateral elevation of that somite and possessing tubercles on anterior and posterior border and a seta at its posterolateral angle. Somites 5 and 6 similar, having first lateral elevation margin that does not extend entire length of somite, stopping prior to reaching posterior border; second lateral elevation lacking; third lateral elevation similar to those of prior somites except that those of the fifth and sixth somites possess two setae. Sixth somite 


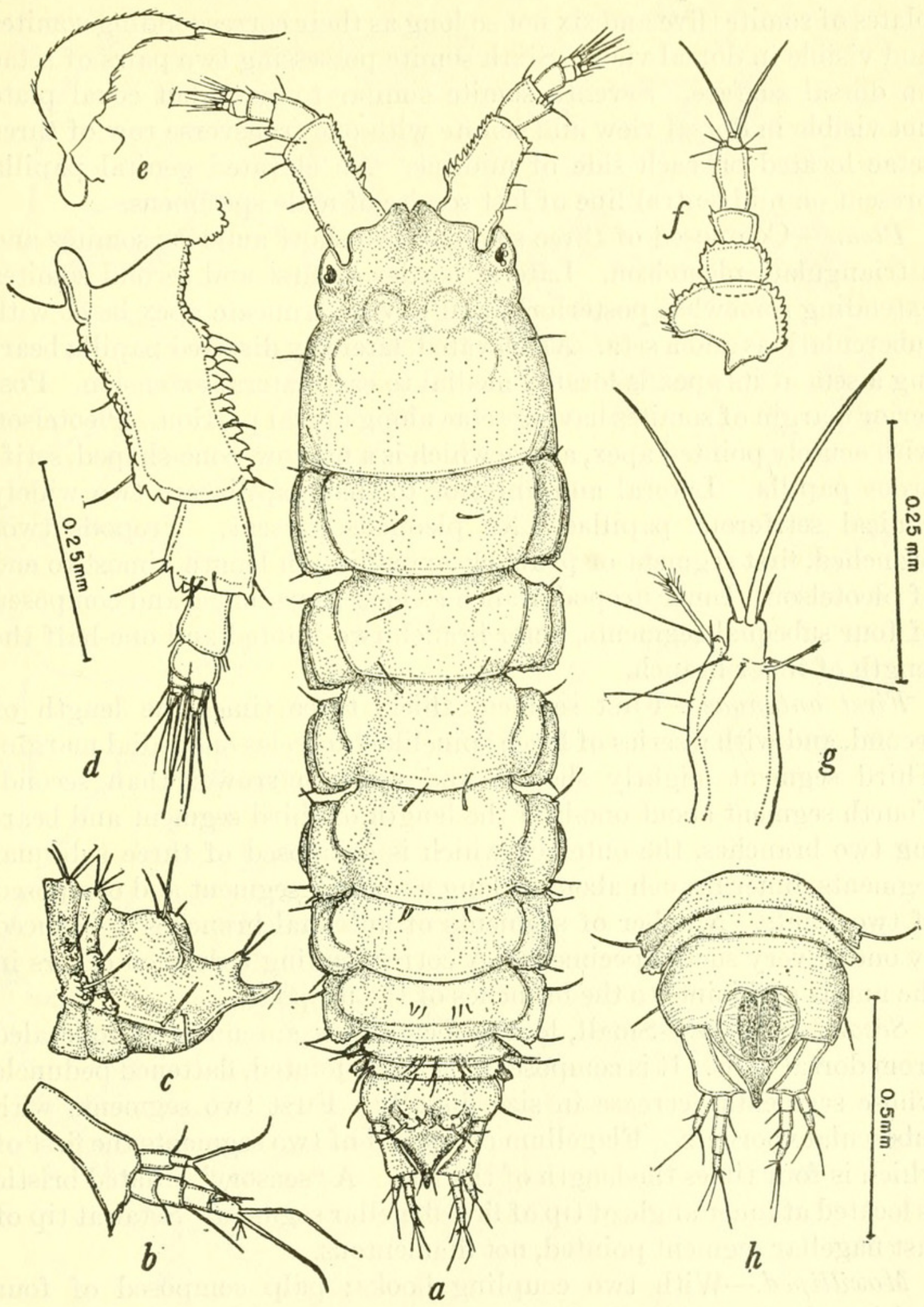

Figure 41.-Synapseudes intumescens, new species, female paratype: a, Dorsal view; $b$, uropod, right; $c$, lateral view of abdomen; $d$, first antenna, right; $e$, gill-like structure within carapace, right; $f$, second antenna, right; $g$, flagellum of second antenna, left; $h$, ventral view of abdomen. (Magnifications: $b, d, e$, as given for $d ; c, f, h$, as given for $h$.) 
with one seta at posterior angle of third lateral elevation. Coxal plates of somites five and six not so long as their corresponding somites and visible in dorsal view. Sixth somite possessing two pairs of setae on dorsal surface. Seventh somite similar to sixth but coxal plate not visible in dorsal view and somite with one transverse row of three setae located on each side of midline. An elevated genital papilla present on midventral line of last somite of male specimens.

Pleon.-Composed of three somites, two short anterior somites and a triangulate pleotelson. Lateral border of first and second somites extending somewhat posteriorly and having truncate apex beset with tuberculations and a seta. An elevated, laterally directed papilla bearing a seta at its apex is located medial to each lateral extension. Posterior margin of somites having setae along dorsal portion. Pleotelson with acutely pointed apex, above which is a narrow, cone-shaped, setiferous papilla. Lateral and anterior to that papilla are two widely conical setiferous papillae. No pleopods present. Uropods twobranched, first segment or peduncle extending in length almost to end of pleotelson. Inner uropod branch as long as peduncle and composed of four subequal segments, outer branch two-jointed and one-half the length of inner branch.

First antennae.-First segment thick, three times the length of second, and with a series of large spinelike tubercles on medial margin. Third segment slightly shorter and much narrower than second. Fourth segment about one-half the length of third segment and bearing two branches, the outer of which is composed of three subequal segments, inner branch about as long as fourth segment and composed of two joints. Number of segments of antennal branches is reduced by one in very small specimens. A corresponding reduction occurs in the number of joints to the branches of the uropods.

Second antenna.-Small, located below first antenna and concealed from dorsal view. It is composed of a three-jointed, flattened peduncle whose segments decrease in size distally. First two segments with tuberculate borders. Flagellum composed of two segments the first of which is four times the length of the last. A "sensory" ciliated bristle is located at inner angle of tip of first flagellar segment. Setae at tip of last flagellar segment pointed, not filamentous.

Maxilliped.-With two coupling hooks; palp composed of four articles, the first two of which are wider than endognath. Toothed setae present on medial margin of last three palp segments.

First pair of maxillae.-Composed of two lobes and a biflagellated appendage. Inner lobe with 4 apical setae, outer lobe with 10 apical setae. Biflagellate appendage, which is located external to outer lobe, appears to be two-jointed, last joint bearing two elongate flagellalike spinulate setae, both of which exceed combined length of prior segments. 


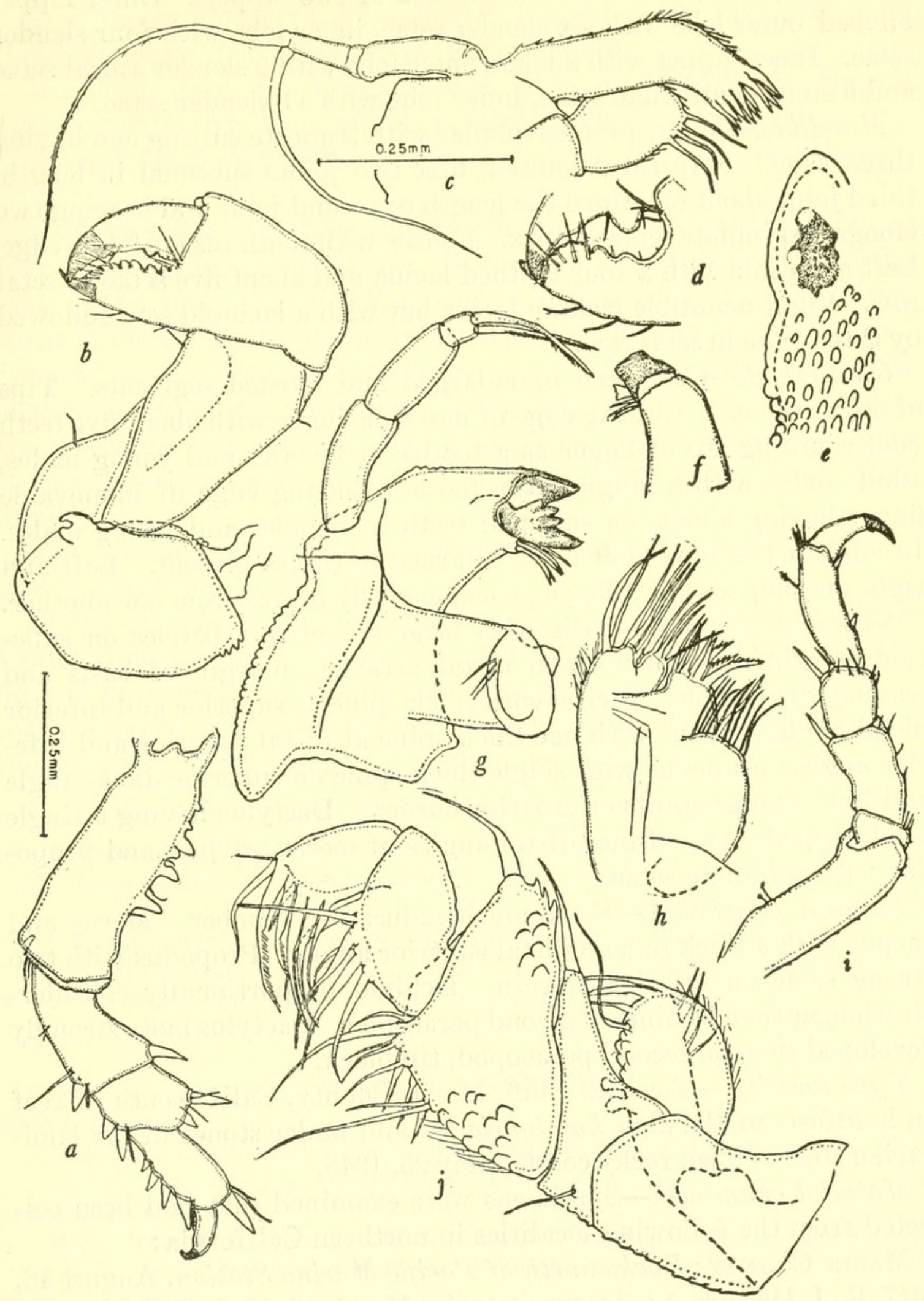

FigUre 42.-Synapseudes intumescens, new species, female paratype (except where indicated): $a$, Second peraeopod, right; $b$, gnathopod, left; $c$, first maxilla, right; $d$, gnathopod, left (male paratype); $e$, eye region, left; $f$, incisor process, right mandible; $g$, left mandible; $h$, second maxilla; $i$, seventh peraeopod, right; $j$, maxilliped, right. (Magnification: $a, b, d, i$, as given for $a$; all others as given for $c$.) 
Second pair of maxillae.-Composed of two lappets. Outer lappet bilobed, outer lobe with six slender setae, inner lobe with four slender setae. Inner lappet with 2 lobes, outer lobe with 3 slender apical setae and 5 stout denticulate setae, inner lobe with 11 slender setae.

Mandible.-Molar process tubular with truncate cutting end having three setae. Palp three-jointed, first two joints subequal in length, third joint about one-third the length of second joint and bearing two elongate spinulate setae at apex. Incisor with toothless knifelike edge. Left mandible with a four-toothed lacina and about five setae in setal row. Right mandible lacking lacina but with a lacinoid seta followed by three setae in setal row.

Gnathopod.-Composed of enlarged and twisted segments. Tips of fingers black. Cutting edge of movable finger with about five teeth (not counting tip of finger as a tooth) in females and young males, adult males with a single large tooth. Cutting edge of immovable finger having about ten subequal teeth in females and young males. In adult males fewer but more enlarged teeth are present. Left and right gnathopods not differing conspicuously in size from one another.

Second peraeopod.-Basis with large spinelike tubercles on superior margin. Ischium set in distal articular margin of basis and scarcely discernible. Merus with thick spine at superior and inferior distal angles, carpus with one thick spine at distal superior and inferior angles, propodus with single thick spine on superior distal angle and four similar spines on inferior border. Dactylus having a single black-tipped claw. Inner distal angles of merus, carpus, and propodus with spinulate setae.

Seventh peraeopod.-Setae much reduced in number. Merus and carpus with a thick seta on distal superior angle. Propodus with two strong setae on inferior margin. Ischium proportionally considerably longer than ischium of second peraeopod. Dactylus more strongly developed than on second peraeopod, tip black.

Type locality.-Tomales Bluff, Marin County, Calif., south of reef on holdfasts of the alga Laminaria sp. and under stones in the laminarian zone of open rocky coast. May 23, 1948.

Material examined.-Specimens were examined that had been collected from the following localities in northern California:

Marin Countr : Rocks north of Pacific Marine Station, August 18, 1947, R. J. Menzies, 1 ovigerous female; March 22, 1948, R. J. Menzies, 3 males, 3 females, 1 juvenile; May 12, 1948, R. J. Menzies, 1 female; May 15, 1948, Margaret Barr, 8 females, 3 ovigerous, 2 juveniles; Tomales Bluff, bay side, November 28, 1947, R. J. Menzies, 1 male; May 23, 1948, R. J. Menzies, 2 males, 3 females; Tomales Point, ocean side, August 18, 1947, R. J. Menzies, 1 female, May 23, 1948, 3 males, 3 females; Tomates Point, reef, November 30, 1947, R. J. Menzies, 1 male young; May 23, 1948, R. J. Menzies, 11 males, 19 females, some 
ovigerous; June 9, 1948, R. J. Menzies, 11 males, 9 females, 7 ovigerous. San Mateo County: Moss Beach, December 26, 1947, Margaret Barr, 2 males, 1 female with empty marsupium.

Monterey County: Carmel Cove, July 18, 1947, T. R. Howell, 1 male, 1 ovigerous female; July 6, 1947, J. Davis, 4 specimens.

Geographical distribution.--Marin County to Monterey County, Calif.

Ecology,-The collections indicate the species to be abundant in and just above the laminarian zone. Specimens were found on the holdfasts of the algae Egregia, Macrocystis, and Laminaria; on the bryozoans Filicrisia sp., Tricellaria occidentalis, and Scrupocellaria californica; on the dorsal surface of the sea-star Pateria miniata and the abalone Haliotes sp.; and on and under rocks in the laminarian zone. One specimen was collected from a Mytilus californianus bed. The species appears most abundant at wave-swept open rocky coast localities.

Reproduction.-Ovigerous specimens were found from May to August inclusive and in December.

Types.-Type specimens are deposited in the following institutions: United States National Museum, female holotype, No. 87416, allotype, figured paratype, and 3 male and 5 female paratypes. Allan Hancock Foundation, 2 male and 2 female paratypes. Pacific Marine Station, 11 male, 19 female, and 1 juvenile paratypes.

\section{KEY TO THE KNOWN SPECIES OF THE GENUS SYNAPSEUDES}

$a^{1}$. Inner border of first joint of first antenna with conspicuous spines.

$b^{1}$. Dorsal surface of pleotelson smooth; Cape Verde Islands.

heterocheles (Vanhöffen)

$b^{2}$. Dorsal surface of pleotelson with 3 setiferous elevated swellings;

California intumescens, new species

$a^{2}$. Inner border of first joint of first antenna smooth, lacking spines;

Hawaii minutus Miller

\section{LITERATURE CITED}

Boone, Pearl Lee.

1923. New marine tanaid and isopod Crustacea from California. Proc. Biol. Soc. Washington, vol. 36, pp. 147-156.

Miller, Milton Albert.

1940. The isopod Crustacea of the Hawaiian Islands (Chelifera and Valvifera). Occ. Pap. Bernice P. Bishop Mus., vol. 15, No. 26, pp. 295-321, 9 figs.

VANHÖFFEN, ERNST.

1914. Die Isopoden der Deutschen Südpolar-Expedition 1901-1903. Deutsche Südpolar-Exped., vol. 15, Zool. 7, pp. 449-598, 132 figs.

Whitelegge, Th.

1901. Isopoda I. Crustacea Part 2. Scientific results of the trawling expedition of H. M. C. S. Thetis off the coast of New South Wales.

Mem. Australian Mus., vol. 4, pt. 3, pp. 201-246, 23 figs. 


\section{$2 \mathrm{BHL}$ Biodiversity Heritage Library}

1949. "A new species of Apscudid crustacean of the genus Synapseudes from Northern California (Tanaidacea)." Proceedings of the United States National Museum 99, 509-515. https://doi.org/10.5479/si.00963801.99-3251.509.

View This Item Online: https://www.biodiversitylibrary.org/item/32791

DOI: https://doi.org/10.5479/si.00963801.99-3251.509

Permalink: https://www.biodiversitylibrary.org/partpdf/20656

\section{Holding Institution}

Smithsonian Libraries

\section{Sponsored by}

Smithsonian

\section{Copyright \& Reuse}

Copyright Status: NOT_IN_COPYRIGHT

Rights: https://www.biodiversitylibrary.org/permissions/

This document was created from content at the Biodiversity Heritage Library, the world's largest open access digital library for biodiversity literature and archives. Visit BHL at https://www.biodiversitylibrary.org. 